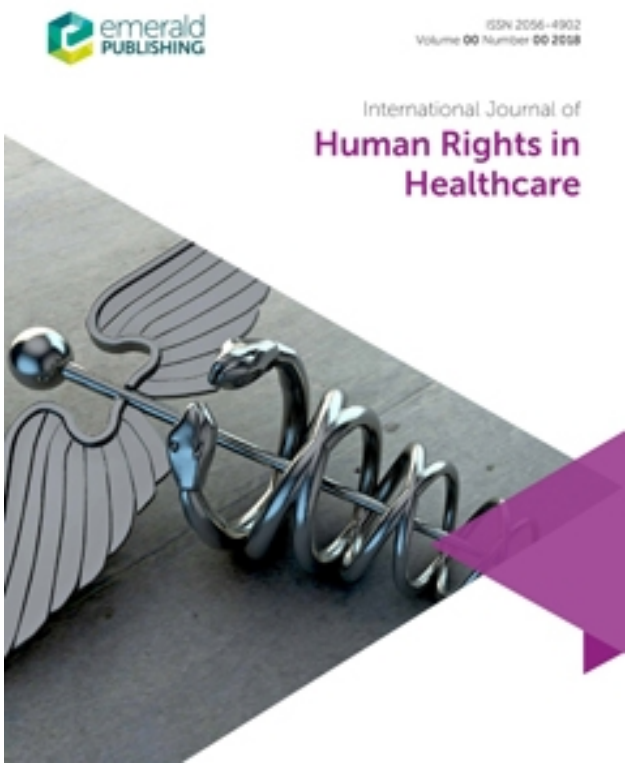

\title{
A Very Lucrative Liquid: The Emerging Trade in Human Milk as a Form of Reproducive Exploitation and Violence Against Women
}

\begin{tabular}{|r|l|}
\hline Journal: & International Journal of Human Rights in Healthcare \\
\hline Manuscript ID & IJHRH-07-2019-0058.R1 \\
\hline Manuscript Type: & Viewpoint Paper \\
\hline Keywords: & gender, human rights, crime, civil society \\
\hline \multicolumn{2}{|l}{} \\
\end{tabular}

\section{SCHOLARONE $^{\text {M }}$ Manuscripts}


A VERY LUCRATIVE LIQUID: THE EMERGING TRADE IN HUMAN MILK AS A FORM OF REPRODUCTIVE EXPLOITATION AND VIOLENCE AGAINST WOMEN

\section{INTRODUCTION}

In recent decades, extensive work has been done worldwide to promote breastfeeding (Akre, Gribble, \& Minchin, 2011). Healthcare professionals routinely emphasise that human milk is the gold standard for infant feeding, while research continues to show the benefits of breastfeeding to both mother and infant. Demand for human milk has therefore expanded, especially in developed settings like the United States (US) and United Kingdom (UK), as increasingly diverse families seek perceive the benefits of milk for feeding even where a parent is unavailable or unable to produce it_herself(Dutton, 2011). However, markets now exist in human milk not just for infant feeding, but also that market milk as a nutritional or fitness supplement, an alternative medicine or treatment regime, and a clean eat for those shunning dairy and other commercially produced milks (Steele, Foell, Martyn, \& Freitag, 2015; Steele, Martyn, \& Foell, 2015). Recently, technology has offered new ways for those seeking human milk to find it easily, with websites, social media platforms and companies offering opportunities to buy, share, and sell milk (Geraghty et al., 2013; Keim et al., 2014).

Awareness of milk banking_-a provision where a service collects, screens, processes, and hands out, usually by prescription, milk that has been donated by women not biologically related to the recipient__-and the online sharing and sale of human milk, as well as medical research using the milk and its components, have brought its value into sharper focus, and consequently raised ethical issues. In some jurisdictions, human milk, like blood, is regulated 
as a body product and thereby only able to be given altruistically, while other jurisdictions either are silent on sale, or instead, regulate milk as a food or via private law, allowing it to be bought and sold (David, 2011). The legal frameworks around human milk sale are varied. Some now argue, though, human milk should have an explicit monetary and economic value, even proposing its inclusion in gross national product (Aguayo \& Ross, 2002). Others suggest women should be paid for its production, both for breastfeeding and expressing milk, as these are forms of work, while some engage a more limited proposal of compensation where a woman is feeding a child other than her own (Carter \& Reyes-Foster, 2016). What is clear is that these claims have (re)opened discussion both of human milk as a commodity and breastfeeding as a service. While the ethics of breast milk sale continue to be debated, forprofit entities have moved into the space. Mirroring what happened with human blood, which resulted in the World Health Assembly (1975) expressing serious concerns about the impact of for-profit enterprises in interfering with health services in developing countries, as well as in crowding out altruistic driven blood donations, we are left with questions about the ethics of commodifying human milk, and concerns about exploitation and trafficking,

Most recently issues around the emerging market were highlighted when Utah-based Ambrosia Labs, sold human milk collected from Cambodian women to be sold in the US, drawing international controversy and comment (AFP, 2017; Boseley, 2017; Forster, 2017; Wong, 2017). The company, on its now defunct website, claimed to be the first company to make breast milk produced overseas commercially available in the US. It stated that it provided an income opportunity for women in Cambodia, whose own babies are older than six months old. However, the government swiftly suspended the operation, citing concerns about local children's nutritional needs and laws on trafficking in body parts (AFP, 2017; Boseley, 2017; Forster, 2017; Wong, 2017). 
The exploitative nature of the business operation was also discussed as it was noted by investigative journalists that the women were being paid a mere US\$0.64 an ounce, typically making a little over US\$7 a day pumping as their primary job, while the company was selling the milk for US\$4 an ounce (Wilson, 2017). Ros Sopheap, the director of NGO Gender and Development for Cambodia (GDC), was cited stating that there had been intentional targeting of poor women who lack other job options, while others noted substantial issues around the market and the failing to address the structural issues that drove these women to sell their milk (Wilson, 2017). Indeed, while explicit charges around "trafficking in persons" and "violence against women" were not directly raised by the government, only trafficking in body parts and products, UNICEF's Cambodia spokeswoman Iman Morooka highlighted that "[b]reast milk banks should not be operated by exploiting vulnerable and poor Cambodian women for profit and commercial purposes". UNICEF also stated to Reuters that "[b]reast milk could be considered as human tissue, the same as blood, and, as such, its commercialization in Cambodia should not be supported" (Thomson Reuters Foundation, 2017).

The ethical considerations, and also the issue of regulating the trade worldwide, became apparent. While many believe that consent lays at the heart of whether the arrangement is exploitative or violent, others were quick to suggest that structural issues mean that all milk sale by intermediaries amounts to the wrongful commoditisation of women's bodies and therefore violence against women through reproductive exploitation. Questions arise, including: is the commercialisation of milk a form of exploitation of women's bodies? Does human milk sale raise specific issues around trafficking in persons, like we have seen with surrogacy, where women are held, their diets dictated, and their freedom limited? Are the current ethical and international legal approaches sufficient to address the continuum of exploitation that could exist around this new trade? 
Notably, much of the literature to date has focused on the nutritional integrity of the milk and the health risks for infant and adult consumers (Geraghty et al., 2013; Keim et al., 2014; S Steele, Martyn, \& Foell, 2015; Sarah Steele, Foell, et al., 2015). Ethical concerns of a broader nature, like whether human milk should be commercialised, collected by public entities as a collective resource, or altruistically given, have all been tenuously linked to women through the figure of consent (see, for example, Hartmann, 2019 for a comprehensive list of hazards related to human milk use and exchange). While discussions about ethical concerns in relation to the use of women's bodies exist from feminist or gender justice perspectives (see, for example, Dickenson, 2002), the bulk of the debate tends to remain limited to the consideration of technical and operational hazards, without being explicit enough in recognizing gender-specific issues and potential inadequacies of the current framework to address potential forms of exploitation around human milk.

By responding to the Cambodian case as one of trafficking in body parts, an implicit assumption was exposed: considerations around human milk allows ethical resolutions that are not gender-focused and exist within generic ethical spaces. However, international press coverage laid bare the issues around reproductive exploitation and the potential for this industry to draw towards behaviours of the past where slaves were exploited to feed other women's infants. We therefore begin by exploring the current issues in the space, detailing both historic and contemporary structural injustices experienced by women selling their milk, and exploring the ethical and legal issues marked out at present. We then move to explore potential issues for the future as the market evolves further, detailing considerations for policy makers and the international community. We finish by exploring what steps must be taken to prevent further exploitation and potential violence against violence against women in this space.

\section{CONTEMPORARY ISSUES AROUND HUMAN MILK SALE AND EXPLOITATION}


Human milk has most commonly been discussed with relevance to explicit rights for the mother and infant to engage in breast feeding. The ethical relevance of human milk lies, principally, on the considerable and growing evidence of the central role that breastfeeding plays in the health and long-term development of infants (World Health Assembly, 1992, 2018). Human milk's ethical relevance is hence, of course, even greater when placed in the context of the inherent dignity and worth of the human person enshrined in the Universal Declaration of Human Rights (United Nations, 1948). We note that breastfeeding and the expression of human milk cannot be in fairness disassociated from that which should only result from the appropriate exercise of women's reproductive rights (i.e., pregnancy and birth), breastfeeding cannot be possibly seen as an isolated bodily function. In the spirit of the brotherhood and sisterhood that humans should behave (United Nations, 1948), the moral logical consequence from the inseparability of pregnancy, birth, and any form of human milk expression, is that women who can express milk in excess of that which is required to feed their own infants, could as well help those who cannot produce enough or any. From this perspective, the challenge of making this happen is, then, one of collective/social coordination. Such coordination has taken multiple forms, including peer-to-peer sharing (a largely community-based, informal practice) and milk banking (often a formalised, regulated practice).

Notably, however, demand for milk has been growing. Increased awareness about milk's beneficial qualities, preference for using donated human milk over formula (American Academy of Pediatrics, 2012), and increasing family diversity, have resulted in considerable increases in the demand for human milk (Fein et al., 2008). Indeed, technological and legal developments have meant that a nursing mother may not exist within a family structure. For example, the mother may be deceased, having passed away during or after birth or even prior $\underline{\text { to conception, as egg freezing and in-vitro fertilisation making posthumous conception now }}$ 
possible, yet controversial (Collins, 2005; Simana, 2018). Further, a mother may never have been part of the intended family unit at all, with some gay, queer, transgender, non-binary, and others using surrogates who do not then form part of the family and may have no further involvement in the infant's feeding after delivery. Additionally, the rise of risk reducing $\underline{\text { surgeries and breast cancer detection in younger women, alongside elective surgical procedures }}$ like breast implants that may impact on ability to breastfeed, have increased the pool of mothers unable to feed themselves but who may still prefer human milk, alongside mothers who for milk supply or other reasons may be unwilling or unable to feed the infant themselves (Roberts, Ampt, Algert, Sywak, \& Chen, 2015; Williams, 2018).

Meanwhile, adult consumptionintake has increased as consumers see uses in sports nutrition, alternative medicine, and "clean" eating (Forgues, Mazanov, \& Smith, 2017; Steele, Foell, et al., 2015). With such growing demand, as well as because of limited supply, seareity has spikedthere has been insufficient milk available for all of those seeking it for infant-feeding, especially in the milk-banking provision, where limitations on who can access the banks and for what purpose -have been implemented (DeMarchis, Israel-Ballard, Mansen, \& Engmann, 2017)._-Alongside informal sharing networks (Akre et al., 2011; Fein et al., 2008; O’Sullivan, Geraghty, \& Rasmussen, 2016), companies, and online commercialisation spaces have emerged. Other options like Prolacta are expensive and may be out of reach for many caregivers, and therefore private mechanisms for sale or exchange may be preferred (Pollack, 2015). None of $t$ These private mechanisms of dealing with scarcity are not new, however; in many respects, with human milk banks havinge existed since the early 1900s, and wet-nursing has, both in paid and unpaid forms, existinged for millennia (Mayerhofer, 1954; Moro, 2018).

However, new technologies and improved logistics have changed previous practices and created the possibility for new ones. Among these, perhaps the most important ones have been online platforms that facilitate trade, devices and accessories that facilitate the expression, 
adequate storage, and transportation of human milk across vast distances, and developments in biomedical research that require cells or proteins from human milk (O'Sullivan et al., 2016). Indeed, these very developments made it possible for a US-based company to initiate collection of milk from mothers in poverty in Cambodia, ship it internationally, and distribute it to buyers in the US.

Such a capacity to move milk, locally, nationally and internationally to meet growing demand raises ethical, legal and social questions, but notably, while these considerations are beginning to be discussed, commercial interests are already crowding out altruist interest in the appropriation of available supplies. For example, Miracle et al.- (2011) show that the International Breastmilk Project (IBMP), a not-for-profit created to ship human milk from the US to developing countries in need, had by 2011 sent donations of about 260,000 ounces of human milk; these donations represented only about 25 percent of the human milk donations received by IBMP. The remaining milk—all 75 percent of it—was sold by IBMP to Prolacta, a private company, which sells at a considerable profit, human milk products for neonatal care. Further to this, while corporations have the proprietary ability via their technology to greatly $\underline{\text { reduce the risks potentially posed by milk, this technology is not widely available at a low cost }}$ to most caregivers, having been subject to intellectual property protections and reduced the potential for research into scalable solutions. With increased adult consumption, such reallocation may mean that there is a shift from meeting the demand from hospitalized neonates, one of the most vulnerable populations in need (Kim \& Unger, 2010), to the adult market.

Another consideration met with some interest has been the safety of the milk for consumption both by infants and those adults who are immune compromised in light of an emerging pricing structure that sells the milk by volume, and thereby incentivises "wateringdown". Studies have found, for example, the presence of bovine DNA in samples acquired through online channels that were supposed to exclusively contain human milk (Keim et al., 
2015). Bacterial, viral and contaminant risks have also been highlighted (Keim et al., 2014; Sarah Steele, Martyn, et al., 2015). Consequently, government and professional bodies have recommended against acquiring milk online. For example, United States Food and Drug Administration guidelines recommend against the use of human milk obtained directly from individuals or through online means (US Food and Drug Administration, 2019). This is recommended as well by the American Academy of Pediatrics (Committee on Nutrition, Section on Breastfeeding, 2017).

However, the Cambodia case internationalised existing questions about the exploitation of minority women's bodies which were already emerging in the US, where commercialisation had progressed rapidly in the digital age. Indeed, local protests against biomedical companies in Detroit in the US resulted in grass-roots campaigns against a company that evoked imagery of slavery and using African-American women like dairy cows (Harrison, 2019). In the US, where commercialisation of human milk and the operation of Ambrosia Labs took place, it is notable that wet-nursing historically marked out forms of racialized reproductive labour, which served to divert breast milk from marginalized babies to more privileged ones. Estimates suggest that roughly twenty per cent of slave-owning families in the US utilized enslaved women as wet nurses for their white infants (Blum, 1999). Newspapers from the eighteenth and early nineteenth centuries featured advertisements for black wet nurses, either to employ or to purchase as slaves (Spruill, 1988). Such connections were drawn directly to commercial practices of milk banking in the US, and around biomedical companies use of minority women, particularly African-American women, for commercial gain and for the use of the socioeconomically privileged, many of whom are white (Harrison, 2019). Indeed, in exploring why Ambrosia Labs had used Cambodian women, it was noted how difficult the American market in milk had become in light of recent protests and boycotts, and thereby how international markets offered a more perfect solution (Wilson, 2017). 
Given the possibility that for-profit companies have to considerably increase the perceived value of their products through investments in research and development, capital, and marketing (Dutton, 2011; Ganapathy, Hay, \& Kim, 2012; 2017), the relative competitive and comparative advantages they can build and acquire through these can create perverse incentives to export human milk to locations where the price and therefore profits might be bigger, as well as to import human milk from locations where the costs is much lower, and even perhaps its availability bigger. In practical terms, this situation could result in the draining of human milk from poorer countries into richer ones, the exploitation of women and girls in developing settings, and even potentially the recruitment and harbouring of women for the purpose of milk "farming" like has been seen around surrogacy and "baby farming". We explore this potential in the sections that follow.

\section{FUTURE ISSUES AROUND HUMAN MILK SALE}

At present, much of the human milk industry rests on either the sale of milk by women who have produced an excess, or on women in socio-economic deprivation who are engaged to pump in exchange for financial or other incentives. Where pumping milk is done explicitly for sale of that milk, we have seen already that there are demands for dietary shifts by the women expressing the milk (no caffeine or alcohol, vegetarian/vegan/gluten free/paleo/clean- eating etc all feature in advertisements on onlythebreast.com, for example), and also behavioural changes around exercise, residency, and number of times pumping per day (Keim et al., 2014). Where excess milk is produced, it is often shared, as the conditions of expressing it and storing it often do not meet commercial demands (American Academy of Pediatrics, 2012). It is therefore likely that the commercial market will move more towards engaging women for the purposes of pumping, rather than the purchase of pre-existing excess supplies. 
Links to surrogacy exploitation becomes apparent in this new configuration where lifestyle and diet become part of the contractual terms of sale. Surrogacy arrangements reported in research have observed women being kept in hotels or other residences where their activities and in-takes can be monitored to comply with the demands of intended parents (Duong, 2012), although framing is often placed on these provisions as a benefit to the surrogate who often comes from poverty and therefore is provided with food and care she otherwise would not receive. Past cases have involved women reporting control being placed over their movement, their sleeping patterns and what they are given to eat and drink. The international press therefore picked up on the need to urgently consider surrogacy internationally, and to revise laws. Notably, in 2011, the European Parliament highlighted how:

women and children are subject to the same forms of exploitation and both can be regarded as commodities on the international reproductive market, and that these new reproductive arrangements, such as surrogacy, augment the trafficking of women and children and illegal adoption across national borders (European Parliament, 2011, para. 21).

Again, in 2015, European Parliament condemned:

the practice of surrogacy, which undermines the human dignity of the woman since her body and its reproductive functions are used as a commodity; considers that the practice of gestational surrogacy which involves reproductive exploitation and use of the human body for financial or other gain, in particular in the case of vulnerable women in developing countries, shall be prohibited and treated as a matter of urgency in human rights instruments (European Parliament, 2014, para. 115).

Previously, a report from the European Parliament (2009, p. 25) noted that: 
Respecting, promoting sexual and reproductive health, and protecting and fulfilling reproductive rights is a necessary condition to achieve gender equality and the empowerment of women to enable them to enjoy all their human rights and fundamental freedoms, and to prevent and mitigate violence against women.

It is not unforeseeable that the more extreme cases of human milk commercialisation may result in similar exploitation of women and control over them in order to deliver on demands from buyers about diet and exposure to chemicals and other carcinogens by those producing the milk.

Issues arise around the adequacy of existing international agreements and national laws in covering this possible form of reproductive exploitation. Article 3, paragraph (a) of the Protocol to Prevent, Suppress and Punish Trafficking in Persons defines "Trafficking in Persons" as:

the recruitment, transportation, transfer, harbouring or receipt of persons, by means of the threat or use of force or other forms of coercion, of abduction, of fraud, of deception, of the abuse of power or of a position of vulnerability or of the giving or receiving of payments or benefits to achieve the consent of a person having control over another person, for the purpose of exploitation. Exploitation shall include, at a minimum, the exploitation of the prostitution of others or other forms of sexual exploitation, forced labour or services, slavery or practices similar to slavery, servitude or the removal of organs.

What is unclear here is whether forced milk sale should rightly be considered forced labour or the removal of organs, or whether the inherently gendered nature of this exploitation is deserving of the addition of a further category of reproductive exploitation. Cambodia in its 
statements clearly devised that it was able to stretch its laws on trafficking in organs to include products from human organs including human milk, which marks a stark departure from the law in other jurisdictions in which human milk is often classified differently due to its renewable nature (although such a clarification ignores the energy, nutrients and labour of the producer of the milk - the mother). While Cambodia investigated the case, suspending the company from operating in the country, the language government officials used in the international press drew direct links to the organ trade and surrogacy, both of which have attracted interest internationally.

However, law reform has not yet been considered internationally, and the human milk and reproductive exploitation remain under-discussed in the anti-trafficking and violence against women context. For example, the WHO's Principles on the donation and management of blood, blood components and other medical products of human origin: Report by the Secretariat, (2017) classifies breast milk among a group of medical products of human origin. These "biological materials that are derived wholly or in part from the human body and are intended for clinical application" also include blood, plasma, ova, sperm and other types of tissue. Most of those materials come with guidance around how they should be selected, screened and tested, but notably have been interpreted not as organs for the purposes of international laws on trafficking, by-and-large.

There is also a failing to address the potential for overlapping forms of exploitation, where women are exploited as surrogates and then forced to provide milk not just for the infant they birthed, but also potentially for others. Indeed, we have seen cases of women deprived of their liberty for the purposes of surrogacy and decoupling this from their production of milk for infant feeding would be problematic. It is further to be considered that women may be forcibly engaged as surrogates in the most egregious cases, where an overlap with sex trafficking may emerge through the rape of the women (Abdullah, 2019). It is therefore critical 
to consider reproductive trafficking alongside other forms of violence against women, as but one expression of the various human rights violations that women experience by virtue of their gender.

By placing the most extreme cases of exploitation for human milk as a form of labour trafficking, alternatively, the issue becomes the overlooking of the implicitly gendered nature of the violence which can only be directed at women who are lactating. It ignores that many women who are engaged in developing settings have few financial options, low levels of literacy, and by virtue of being new mothers often lack options to gain other employment due to discriminatory, patriarchal systems. Knowledge about the health risks to both the mother and their infant of her pumping for profit are also problematic, and many investigations by the press have raised questions about levels of knowledge and whether consent is real (Forster, 2017; Wilson, 2017; Wong, 2017). It is also worth noting that such obfuscation of the genderbased aspects of the trade also overlooks that demand for human milk also arises from inadequacies in healthcare for mothers (e.g. a lack of availability or insurance coverage for lactation consultation), and also by a lack of leave for new mothers and support for breastfeeding in workplaces in places like the US. Indeed, by moving discussion outside of a gendered lens, and by covering the most extreme cases of human milk exploitation under a framework of labour trafficking, the structural causes of reproductive exploitation may be concealed.

However, moving beyond the most extreme cases of deprivation of liberty as an evident and concerning form of violence against women, it is worth noting that milk production for commercial sale even with consent inherently raises gendered exploitation as an issue. To meet unmet demand for human milk, it is notable that this can only be satisfied by women and their bodies given they are the only humans who produce human milk. Therefore, in principle, there is an unequal burden by design on women that is likely to have a physical and emotional toll 
on them. The physical demands these impose exclusively on women which not only consume the energy that characterizes labour, but that actually transforms their physical and emotional states differently than any other job (Hartmann, 2019). The transaction nature of a commercial arrangement equates payment as remunerating women for these inconveniences and the energy spent — a right also enshrined in the Universal Declaration of Human Rights, Article 23 (United Nations, 1948). However, such compensation cannot offset many of the physical and emotional burdens being placed directly on women's bodies, and only on women's bodies.

It is notable that the commercial human milk sale is inordinately enticing for women who lack other remunerable options, like the women who were identified in the Cambodian case, or even for women in US who, while employed, have been shown to experience steep declines in their annual income due to breastfeeding constraints faced in the labour markets (Rippeyoung \& Noonan, 2012). A simple analysis of the economics of human milk can help illustrate why this is the case. In the US, members of a form of human milk bank termed Mother Milk Cooperatives, can receive compensation for human milk "donations" in the order of US\$500-800 (Clinton Global Initiative, 2019). This represents between US\$17-27 a day, levels of compensation that are between 3 to 5 times higher than those of about 46 percent or about 3.5 billion people who rely on USD 5.5 a day to survive (World Bank, 2019). Indeed, the income that "donating" human milk can generate has been discussed as a taxable source of income (Zelenak, 2017). This is not surprising given that several studies Bartick et al., 2017; Bartick \& Reinhold, 2010) have shown not only that the opportunity costs of breastfeeding not being the exclusive source of nutrition during the first 6 months of infant life are in the order of US\$13-14 billion. Another study (Smith, 2013), quantifies the annual value of human milk production at exceeding US\$3.6 billion in Australia, under US\$1 billion in Norway, and a massive US\$45 billion in the United States. This study estimates, however, that annually about US\$63 billion in the US, about US\$600 million in Norway, and US\$4 billion in Australia are 
lost because women's right to lactate are not protected, and because competing milk sources (e.g., infant formula) crows out human milk production. Aguayo \& Ross (2002), estimated that in Francophone West Africa, children under 35.9 months old consume more than 1.1 billion litres of human milk in a year; this, the authors estimate, could have an opportunity cost of about US\$2 billion, or about US\$412 per infant (US\$1.13 per day), if the same milk were to be sourced from breastmilk substitutes.

Another way to understand the economics of human milk and the perverse incentives that commodifying it can create is by looking at the potential volume of milk that a woman can generate and the income she could collect for this volume. The studies mentioned above assume an estimate milk production per woman at about $850 \mathrm{~mL}$ or about 30 ounces (this is for women who are exclusively breastfeeding) (Smith, 2013). US human milk banks and internet-based trading sites sell an ounce of milk at around US\$3 or more, which means that a lactating woman could sell her daily production for about US\$90 a day. Compensation for wetnursing can range between US\$50-200 per day in the US and in China (Smith, 2013). However, the Cambodian case demonstrated that women receive much lower compensation when they are in developing settings, and also where other charges around testing, dietary supplementation, and food or accommodation specifications must be met. Indeed, this case highlighted how much of the profit does not flow on to women, but to intermediaries.

There are also questions about whether the conditions are adequate and the compensation fair in light of what the milk is sold for in the end market. For example, while as stated above, a woman who sells her entire expression of milk in a day could theoreticallye.g. in the very best market conditions and in developed settings - earn about US $\$ 90$, intermediaries selling milk in the US can earn for the same volume about US $\$ 1,000$. Private producers of even more specialized human milk-based products like "fortifiers" can earn up to about US\$5,300 (Fentiman, 2009; Smith, 2013). In yearly terms, this differences add up to 
astonishing differences: even if a woman manages to maintain her milk production at the estimated $850 \mathrm{~mL}$ for every single day in a year, she could earn a maximum total of US $\$ 32,850$, while private companies can earn for the same volume of human milk between US\$367,025 and US\$1,939,000. Many have argued that these disparities in income evidence serious ongoing ethical issues, and also clearly indicate the exploitation of women with unfair and unequal levels of compensation. The transactions involving unequally vulnerable parties and considerable market asymmetries which must be addressed.

It is also worth noting non-financial impacts of the growing number of intermediaries. Intermediaries between donors, mothers, and infants remove the possibility of such bonds and might ignore as well cultural sensitivities that if transgressed may result in negative consequences like reduced donation, refusal to accept donated milk, and others (Gürol, Özkan, \& Çelebioğlu, 2014). Emphasis on efficiency, effectiveness, and quality, as in the case of the commercial manufacturing of goods and the provision of services, contributes to further commodify women and the fruits of their body and labour. The emphasis on productivity is made clear by a patent granted on a human milk pumping device:

U.S. Pat. No. 4,772,262, which is hereby incorporated by reference in its entirety, is directed to technology for milk removal. As disclosed in that patent, milk yields increase due to the sensory stimulus provided by the patented breast pump equipment. When milk yield increases, the formulation of milk including many of the valuable immunoglobulins also increase along with living cells, such as macrophages and lymphocytes. Lipids also increase and the mother's body responds to the stimulus by producing higher levels of prolactin that will trigger continuing milk Supply and the secretion of additional nutrients into her milk. (United States Patent and Trademark Office, 2010, pp. 7-8) 
Furthermore, it would be difficult to deny that the advertisement of human milk as a product for sale that is presented professionally packaged, with colourful labels, and memorable names, all while removed from images of the women who expressed it, does not contribute significantly in future commodifying, if no women, at least the biological expression of their bodies. Likewise, by focusing marketing oriented messaging used in their promotion on the "value added" characteristics that separate one company's product from that of another-being the most likely those related to safety and quality — it is likely as well that with time, the deeply human and moving image of a women breastfeeding her child and the maternal bond they represent, will be substituted by one of fear and concern about the quality of the "product".

Indeed, by allowing the commercialization of human milk, the transactional structure of breastfeeding and expressed milk sharing changes. While breastfeeding is the preferred and recommended choice for the wellbeing of mothers and infants, this is at odds with the "wellbeing" of the private enterprise which profits from the cases where there is no breastfeeding. It is also of the interest of these enterprises that no altruistic organizations crowd-in the spaces on which they can profit. This creates considerable incentives for the forprofit enterprises to exercise all their skills and dedicate important resources to absorb as much as the demand for human milk as it is possible, which means displacing breastfeeding (Hartmann, 2019). Among the problematic things these enterprises could do that affect women are: (i) taking advantage of good will of potential donors through questionable emotional and financial inducements; (ii) influencing regulators to create barriers of entry that result in market consolidation and therefore less competition; (iii) offering suboptimal conditions that could result on emotional and physical harm to donors who because of their disadvantageous position might be improperly induced to accept such condition - this could be worsen if women in even direr conditions, for example from other countries, are available (Hartmann, 2019; Pirnay et 
al., 2010); (iv) this and other actions can end up discouraging and deteriorating altruistic attitudes that can lead to donation and facilitation (Pirnay et al., 2010).

While human milk has an extremely high inherent value, the expression of this value in monetary terms, as well as the allocation of this value among those involved, in particular women who play the most relevant role, is not a "naturally occurring" event. It is regulation or the lack thereof, what translates value into money and what determines the allocation of such value among those who participate as producers, intermediaries, and consumers (Dickenson, 2002). Even those who believe in "free markets" would be able to appreciate that the mix of historical and structural abuse, violence, and exploitation against women, incomplete information (e.g., not all participants are well informed nor able to engage in a consensual and free market transaction), and asymmetric power and information (e.g., for-profit enterprises have the advantage in an unregulated market), make consent problematic, and law reform necessary.

\section{CONCLUSION}

The sale of human milk marks a new market where the exploitation of women's bodies becomes possible through the commodification of a purely female produced substance. We have argued that this is therefore an issue of gender justice and equality that must not be structurally removed from exploring violence against women by regarding milk production as labour and human milk as a product that can be bought and sold, especially through intermediaries. Entrenched and evident structural injustices mean that this and other gender related issues should remain in gender-specific ethical and legal spaces, making explicit consideration of trafficking in women and girls for reproductive exploitation critical to consider, while addressing alongside it the commercialisation of body products alongside organ trafficking. 
Allowing the sale of milk would reflect a commodifying and commercialist approach to public health, holding women and girls responsible for improving health outcomes in their communities that are, in reality, tied to systemic and structural racism, classism, and inequalities more broadly. This approach privatises infant nutrition at the expense of true reproductive justice, which demands broad social support for women's human rights (Ross, 2017). With developments in biotechnology facilitating the commodification of reproduction, including the production of human milk and its use (not just for feeding but also biomedical applications), we should note that a new door that has been opened for yet further disregard and degradation of women and girls' humanity, as well as their physical and emotional wellbeing. Respect for human rights and equal justice - particularly for the most vulnerable globally- must be first and foremost in consideration and policy development.

Meanwhile our research on human milk sale must move beyond discussions of public health harms and peer-to-peer exchange, to explore the broader commercialisation of human milk at an international level. Biomedical developments and also technological capacities for shipping and processing milk across vast distances fundamentally shift existing discussions of wet nursing and milk donation which have assumed to be between women or between women and children, rather than to involve legal entities (e.g. companies). Such a discussion must occur within a space that carefully respects breastfeeding and long-held customary practices around infant feeding in diverse cultures, but that addresses the exploitative elements of commercialised trade.

Ultimately, it seems preferable not only to prohibit any kind of financial gains related to human milk by legal entities, but to also explore and enact regulations that address the present and forthcoming issues we detail in this paper. It is critical that governments around the world address the emerging exploitation of women within their countries and across borders, 
while affording women and girls substantial support and protections around maternity and breastfeeding.

\section{BIBLIOGRAPHY}

Abdullah, F. M. (2019). LEGAL AND ETHICAL ASPECTS BEYOND COMMERCIAL SURROGACY : MODERN FORM OF. 22(1), 1-7.

AFP. (2017, March 28). Cambodia bans export of human breast milk after US operation raises concern. The Guardian.

Aguayo, V. M., \& Ross, J. (2002). The Monetary Value of Human Milk in Francophone West Africa: A Profiles Analysis for Nutrition Policy Communication. Food and Nutrition Bulletin, 23(2), 153-161. https://doi.org/10.1177/156482650202300204

Akre, J. E., Gribble, K. D., \& Minchin, M. (2011). Milk sharing: from private practice to public pursuit. International Breastfeeding Journal, 6(1), 8. https://doi.org/10.1186/1746-4358-6-8

American Academy of Pediatrics. (2012). Breastfeeding and the Use of Human Milk. PEDIATRICS, 129(3), e827-e841. https://doi.org/10.1542/peds.2011-3552

Bartick, M. C., Schwarz, E. B., Green, B. D., Jegier, B. J., Reinhold, A. G., Colaizy, T. T., ... Stuebe, A. M. (2017). Suboptimal breastfeeding in the United States: Maternal and pediatric health outcomes and costs. Maternal \& Child Nutrition, 13(1), e12366. https://doi.org/10.1111/mcn.12366

Bartick, M., \& Reinhold, A. (2010). The Burden of Suboptimal Breastfeeding in the United States: A Pediatric Cost Analysis. PEDIATRICS, 125(5), e1048-e1056. https://doi.org/10.1542/peds.2009-1616

Blum, L. M. (1999). At the breast: ideologies of breastfeeding and motherhood in the contemporary United States. Retrieved from http://cambridge- 
primo.hosted.exlibrisgroup.com/primoexplore/openurl?sid=uchicago\&iuid $=24692 \&$ aulast $=$ Blum\&aufirst $=$ Linda\&title $=$ At the Breast: Ideologies of Breastfeeding and Motherhood in the Contemporary United States\&vid=44CAM_PROD\&institution=44CAM\&url_ctx_val=\&url_ctx_fmt=null\&is SerivcesPage $=$ true

Boseley, S. (2017, March 22). Sale of Cambodian breast milk to mothers in US criticised by UN. The Guardian.

Carter, S. K., \& Reyes-Foster, B. M. (2016). Pure Gold for Broken Bodies: Discursive Techniques Constructing Milk Banking and Peer Milk Sharing in U.S. News. Symbolic Interaction, 39(3), 353-373. https://doi.org/10.1002/symb.233

Clinton Global Initiative. (2019). Co-op Campaign to Increase Breastfeeding in Urban Areas. Retrieved July 30, 2019, from https://www.clintonfoundation.org/clinton-globalinitiative/commitments/co-op-campaign-increase-breastfeeding-urban-areas

Collins, R. (2005). Posthumous reproduction and the presumption against consent in cases of death caused by sudden trauma. Journal of Medicine and Philosophy, 30(4), 431-442. https://doi.org/10.1080/03605310591008612

Committee on Nutrition, Section on Breastfeeding, C. on F. and N. (2017). Donor Human Milk for the High-Risk Infant: Preparation, Safety, and Usage Options in the United States. Pediatrics, 139(1), e20163440. https://doi.org/10.1542/peds.2016-3440

David, S. D. (2011). Legal commentary on the internet sale of human milk. Public Health Reports, 126(2), 165-166. https://doi.org/10.1177/003335491112600205

DeMarchis, A., Israel-Ballard, K., Mansen, K. A., \& Engmann, C. (2017). Establishing an integrated human milk banking approach to strengthen newborn care. Journal of Perinatology: Official Journal of the California Perinatal Association, 37(5), 469-474. https://doi.org/10.1038/jp.2016.198 
Dickenson, D. (2002). Commodification of Human Tissue: Implications for Feminist and Development Ethics. Developing World Bioethics, 2(1), 55-63. https://doi.org/10.1111/1471-8847.00035

Duong, K. A. (2012). Human Trafficking in a Globalized World: Gender Aspects of the Issue and Anti-trafficking Politics. Journal of Research in Gender Studies, 2(1), 48-65.

Retrieved from https://www.ceeol.com/search/article-detail?id=103596

Dutton, J. (2011). Liquid Gold: The Booming Market for Human Breast Milk | WIRED. Retrieved July 26, 2019, from Wired website: https:/www.wired.com/2011/05/ff-milk/ European Parliament. (2011). European Parliament resolution of 5 April 2011 on priorities and outline of a new EU policy framework to fight violence against women (2010/2209(INI)) (p. 8). p. 8. Retrieved from http://www.europarl.europa.eu/sides/getDoc.do?pubRef=-//EP//NONSGML+TA+P7TA-2011-0127+0+DOC+PDF+V0//EN

European Parliament. (2014). European Parliament resolution of 17 December 2015 on the Annual Report on Human Rights and Democracy in the World 2014 and the European Union's policy on the matter (2015/2229(INI)). Retrieved from http://data.consilium.europa.eu/doc/document/ST-11855-2012-INIT/en/pdf

European Parliament - Committee on Women's Rights and Gender Equality. (2009). REPORT on Sexual and Reproductive Health and Rights (2013/2040(INI)). Retrieved from http://www.europarl.europa.eu/sides/getDoc.do?pubRef=//EP//NONSGML+REPORT+A7-2013-0426+0+DOC+PDF+V0//EN\&language=EN

Fein, S. B., Labiner-Wolfe, J., Shealy, K. R., Li, R., Chen, J., \& Grummer-Strawn, L. M. (2008). Infant Feeding Practices Study II: Study Methods. Pediatrics, 122(Supplement 2), S28-S35. https://doi.org/10.1542/peds.2008-1315c

Fentiman, L. C. (2009). Marketing Mothers' Milk: The Commodification of Breastfeeding 
and the New Markets for Breast Milk and Infant Formula. Nevada Law Journal, 10, 2981. Retrieved from https://law.unlv.edu/nevada-law-journal/vol10

Forgues, C., Mazanov, J., \& Smith, J. (2017). The paradox of human milk doping for antidoping. Performance Enhancement \& Health, 5(4), 158-165.

https://doi.org/10.1016/j.peh.2017.08.002

Forster, K. (2017, March 17). US Company selling human breast milk stopped by Cambodia export ban. The Independent. Retrieved from

www.independent.co.uk/news/world/asia/human-breast-milk-company-ambrosia-labsselling-us-stopped-cambodia-export-ban-bodybuilders-a7654116.html

Ganapathy, V., Hay, J. W., \& Kim, J. H. (2012). Costs of Necrotizing Enterocolitis and CostEffectiveness of Exclusively Human Milk-Based Products in Feeding Extremely Premature Infants. Breastfeeding Medicine, 7(1), 29-37.

https://doi.org/10.1089/bfm.2011.0002

Geraghty, S. R., McNamara, K. A., Dillon, C. E., Hogan, J. S., Kwiek, J. J., \& Keim, S. A. (2013). Buying Human Milk via the Internet: Just a Click Away. Breastfeeding Medicine, 8(6), 474-478. https://doi.org/10.1089/bfm.2013.0048

Gürol, A., Özkan, H., \& Çelebioğlu, A. (2014). Turkish women's knowledge and views regarding mother's milk banking. Collegian, 21(3), 239-244. https://doi.org/10.1016/j.colegn.2013.05.002

Harrison, L. (2019). Milk Money: Race, Gender, and Breast Milk “Donation.” Signs: Journal of Women in Culture and Society, 44(2), 281-306. https://doi.org/10.1086/699339

Hartmann, B. T. (2017). Ensuring Safety in Donor Human Milk Banking in Neonatal Intensive Care. Clinics in Perinatology, 44(1), 131-149. https://doi.org/10.1016/j.clp.2016.11.006

Hartmann, B. T. (2019). Benefit by design: determining the 'value' of donor human milk and 
medical products derived from human milk in NICU. Seminars in Perinatology. https://doi.org/10.1053/j.semperi.2019.06.005

Keim, S. A., Kulkarni, M. M., McNamara, K., Geraghty, S. R., Billock, R. M., Ronau, R., ... Kwiek, J. J. (2015). Cow's Milk Contamination of Human Milk Purchased via the Internet. PEDIATRICS, 135(5), e1157-e1162. https://doi.org/10.1542/peds.2014-3554

Keim, S. A., McNamara, K. A., Jayadeva, C. M., Braun, A. C., Dillon, C. E., \& Geraghty, S. R. (2014). Breast Milk Sharing via the Internet: The Practice and Health and Safety Considerations. Maternal and Child Health Journal, 18(6), 1471-1479. https://doi.org/10.1007/s10995-013-1387-6

Kim, J., \& Unger, S. (2010). Human milk banking. Paediatrics \& Child Health, 15(9), 595598. Retrieved from https://www.ncbi.nlm.nih.gov/pmc/articles/PMC3009567/ Mayerhofer, E. (1954). Preservation of human milk and the collecting centres from 1907 till to-day. Osterreichische Zeitschrift Fur Kinderheilkunde Und Kinderfursorge, 10, 127140. Retrieved from https://www.cabdirect.org/cabdirect/abstract/19551401715 Miracle, D. J., Szucs, K. A., Torke, A. M., \& Helft, P. R. (2011). Contemporary Ethical Issues in Human Milk-Banking in the United States. PEDIATRICS, 128(6), 1186-1191. https://doi.org/10.1542/peds.2010-2040

Moro, G. E. (2018). History of Milk Banking: From Origin to Present Time. Breastfeeding Medicine, 13(S1), S-16-S-17. https://doi.org/10.1089/bfm.2018.29077.gem

O’Sullivan, E. J., Geraghty, S. R., \& Rasmussen, K. M. (2016). Informal Human Milk Sharing. Journal of Human Lactation, 32(3), 416-424. https://doi.org/10.1177/0890334416651067

Pirnay, J.-P., Vanderkelen, A., Zizi, M., De Vos, D., Rose, T., Laire, G., ... Verbeken, G. (2010). Human cells and tissues: the need for a global ethical framework. Bulletin of the World Health Organization, 88(11), 870-872. https://doi.org/10.2471/BLT.09.074542 
Pollack, A. (2015, March 20). Breast Milk Becomes a Commodity, With Mothers Caught Up in Debate - The New York Times. The New York Times. Retrieved from https://www.nytimes.com/2015/03/21/business/breast-milk-productscommercialization.html

Rippeyoung, P. L. F., \& Noonan, M. C. (2012). Is Breastfeeding Truly Cost Free? Income Consequences of Breastfeeding for Women. American Sociological Review, 77(2), 244 267. https://doi.org/10.1177/0003122411435477

Roberts, C. L., Ampt, A. J., Algert, C. S., Sywak, M. S., \& Chen, J. S. C. (2015). Reduced breast milk feeding subsequent to cosmetic breast augmentation surgery. Medical Journal of Australia, 202(6), 324-328. https://doi.org/10.5694/mja14.01386

Ross, L. (2017). Radical reproductive justice: foundations, theory, practice, critique. Retrieved from https://www.feministpress.org/books-n-z/radical-reproductive-justice Simana, S. (2018). Creating life after death: should posthumous reproduction be legally permissible without the deceased's prior consent? Journal of Law and the Biosciences, 5(2), 329-354. https://doi.org/10.1093/jlb/1sy017

Smith, J. P. (2013). “Lost Milk?” Journal of Human Lactation, 29(4), 537-546. https://doi.org/10.1177/0890334413494827

Spruill, J. (1988). Women's Life and Work in the Southern Colonies. Retrieved from https://books.google.com/books?hl=en\&lr=\&id=VnH35jen4NkC\&oi=fnd\&pg=PR9\&ot

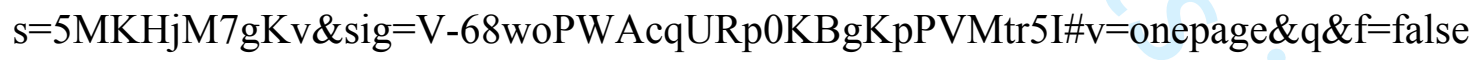

Steele, S, Martyn, J., \& Foell, J. (2015). Risks of the unregulated market in human breast milk. BMJ. https://doi.org/10.1136/bmj.h1485

Steele, Sarah, Foell, J., Martyn, J., \& Freitag, A. (2015). More than a lucrative liquid: the risks for adult consumers of human breast milk bought from the online market. Journal of the Royal Society of Medicine, 108(6), 208-209. 
https://doi.org/10.1177/0141076815588539

Steele, Sarah, Martyn, J., \& Foell, J. (2015). Risks of the unregulated market in human breast milk. $B M J$, h1485. https://doi.org/10.1136/bmj.h1485

Thomson Reuters Foundation. (2017, March 22). U.N. slams sale of Cambodian women's breast milk by U.S. firm. Retrieved from https://www.reuters.com/article/us-cambodiawomen-idUSKBN16T1VE

United Nations. (1948). Universal Declaration of Human Rights - General Assembly resolution $217 \mathrm{~A}$. Retrieved from https://www.ohchr.org/EN/UDHR/Documents/UDHR_Translations/eng.pdf United States Patent and Trademark Office. (2010). US Patent US 2010/0268658 - Method for Collecting, Testing and Distributing Milk. Retrieved from https://patentimages.storage.googleapis.com/2e/c5/47/431a3f8cabdfb0/US20100268658 A1.pdf

US Food and Drug Administration. (2019). Use of Donor Human Milk. Retrieved July 25, 2019, from https://www.fda.gov/science-research/pediatrics/use-donor-human-milk Williams, S. (2018, May 12). 'I was not willing to die for my breasts'": the young women opting for mastectomies.' The Guardian. Retrieved from www.theguardian.com/society/2018/may/12/not-willing-die-breast-cancer-mastectomygenetic-risk-surgery $\% 0 \mathrm{~A}$

Wilson, A. (2017, March 14). Americans Can Now Buy Breast Milk from Cambodian Women Paid Less Than \$10 a Day. Vice. Retrieved from https://www.vice.com/en_us/article/43gx3w/americans-can-now-buy-breast-milk-fromcambodian-women-paid-less-than-10-a-day

Wong, T. (2017, March 29). Cambodia breast milk: The debate over mothers selling milk. BBC News. 
World Bank. (2019). World Development Indicators. Retrieved July 8, 2019, from

https://datacatalog.worldbank.org/dataset/world-development-indicators

World Health Assembly. (1975). Resolution WHA28.72 - Utilization and supply of human blood and blood products. Retrieved from

https://www.who.int/bloodsafety/en/WHA28.72.pdf

World Health Assembly. (1992). Resolution WHA45.34 - Infant and young child nutrition and status of implementation of the International Code of Marketing of Breast-milk Substitutes. Retrieved from

https://www.who.int/nutrition/topics/WHA45.34_iycn_en.pdf?ua=1

World Health Assembly. (2018). Resolution WHA71.9 - Infant and young child feeding.

Retrieved from http://www.who.int/maternal_child_adolescent/documents/a85622/en/,

World Health Organization. (2017). Principles on the donation and management of blood,

blood components and other medical products of human origin Report by the

Secretariat. Retrieved from http://who.int/mediacentre/factsheets/fs279/en/

Zelenak, L. (2017). The body in question: The income tax and human body materials.

Retrieved from http://lcp.law.duke.edu/. 